

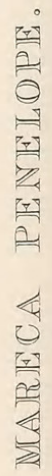




\section{MARECA PENELOPE.}

\section{Widgeon.}

Anas penelope, Linn. Faun. Suec., p. 44.

— fistularis, Briss. Orn., tom. vi. p. 391, tab. xxxv. fig. 1 .

—Wigeon, Vieill. Ency. Méth., Orn., part i. p. 129.

Mareca penelope, Selb. Ill, Brit. Orn., vol. ii. p. 324.

fistularis, Steph. Cont. of Shaw's Gen. Zool., vol. xii. p. 131, pl. 50.

THE Widgeon is a compact and trim little duck, whose structure is equally well adapted for walking on the land and for swimming on the water. Its weight is about two pounds, though some examples may be a trifle more and others a little less. As an esculent it is sometimes remarkably good, particularly when rich and succulent grasses have formed a part of its diet. Unlike the Mallard and Shoveller, which feed in soft and oozy places, or the Scaup, which gathers mollusks from the bottom, the Widgeon wanders over marshes and nibbles the grasses and other plants which there abound, much after the manner of the goose. Even a cursory examination of the peculiar formation of its bill, its feet, and legs will be sufficient to show that they are admirably adapted for such a mode of feeding; and as regards flight, few ducks are better furnished with the means of progression through the air. In disposition it is less shy than its congeners; and from the vast numbers which frequent our eastern and southern coasts during the months of autumn and winter, it affords an abundance of amusement to the sportsman and gunner at those seasons of the year. In all parts of England the Widgeon must be regarded as a winter-visitant; but in Scotland a few remain during the summer and breed. That some Widgeons arrive on the south coast of England from their northern breeding-quarters as early as the month of September I can affirm, since, while on a visit to A. J. B. Beresford Hope, Esq., at Bedgebury Park, Kent, the keeper brought in, on the 28th of that month, as nondescript birds, two which he had just shot, and which proved to be young Widgeons of the year. It is generally stated that the bird does not breed in this country; but that it will occasionally do so in partial confinement is evident from the following note, kindly communicated to me by the Rev. John Fountaine, of Southam, in Norfolk :- "A pair of Widgeons I have had pinioned in my decoy for five or six years have bred this season (1864) and reared their young ones, which I have had plenty of opportunities of watching since they were very small up to the present time, when they are able to fly. This I believe to be an unprecedented occurrence; for I never knew of an instance of the Widgeon breeding in this country, either in a wild or tame state." Granting that the main body of the Widgeons that winter here go northward to breed in March or April, it becomes necessary to state into what countries they proceed for that purpose. According to Mr. Wolley and Mr. Wheelwright it breeds abundantly in Lapland, being one of the most numerous of the birds of that country; and Mr. Proctor informed Mr. Yarrell that a few breed in Iceland, forming their nest generally among low bushes near the edge of the fresh waters. Generally speaking the Widgeon frequents, at one season or the other, the whole of the northern and temperate regions of the Old World, from Iceland in the west to Japan in the east. In Finland it is especially common during summer, as it doubtless is in all the northern portions of the countries within the limits I have mentioned. In China, in India, and in Southern Europe it also occurs during summer as numerously as with us. Loche states that it is found in all the three provinces of Algeria ; and Dr. Baird that it is an accidental visitor to the Atlantic coast of the United States of America. On examining a number of male examples, differences in their plumage may be observed not unworthy the attention of the ornithologist, some having the whole of the shoulder or upper half of the wing white, while in others the same part is mottled with brown. This difference was pointed out to me, in the first instance, by Mr. Fountaine, coupled with the remark that the whiteness of the shoulder shows very conspicuously when the bird is swimming; I consider that the examples thus distinguished are the older birds. The females are more uniform or browner, as may be seen in the accompanying plate.

Speaking of the birds inhabiting Sutherland, Mr. Selby says :- "As the Widgeon had not previously been detected breeding in Britain, we were much pleased to see several pairs upon the smaller lochs near Lairg, which, we concluded, had their nests among the reeds and other herbage which grew in their vicinity. We were not so fortunate as to find one here; but afterwards, upon one of the islands of Loch Laighal, we sprung a female, which was shot from her nest containing seven eggs. It was placed in the heart of a large rush-bush, and was made of decayed rushes and reeds, with a lining of warm down from the bird's body. The eggs were smaller than those of the Wild Duck, and of a rich cream-white colour." Sir William 
Jardine, who accompanied Mr. Selby, mentions that "Widgeons were seen upon Loch Shin, Loch Naver, Loch Loyal, and Loch Hope. They were by no means abundant; and it is possible that the birds in this district were at the most southern limit of their breeding-stations, and bore no proportion whatever to the immense flocks which frequent our coasts in winter." A more recent writer, St. John, in his 'Natural History and Sport in Moray,' says :- “In Sutherland I have found the nest, and in Loch Naver and elsewhere the Widgeon breeds regularly, though not in any great numbers. I have shot Widgeon in this country on the 9 th of September. There was a small flock of eight or nine; and the two which I shot were evidently young, and must have been bred in the neighbourhood. The migrating Widgeon begin to arrive early in October or at the end of September; by the beginning of November there are immense numbers, and their shrill whistle enlivens all the larger lochs and swamps. Towards night every Widgeon seems to be in motion, flying to their feeding-places, either in the shallows or along the edges of the water, where they can get at the grass and water-plants wlich form their food. Their flight is very rapid, and divided into small companies; they flit to and fro in every direction until they settle down to feed. During the daytime they all collect and rest in the centre of the lochs. The Widgeon, like the Teal, is late in acquiring its full plumage ; and in the flocks but a small proportion of Drakes, in full beauty, are seen. It is also late in coming into full season for the table, and is in best condition from February to April. Like other wild fowl, when driven to feed on the sea-shore, it soon loses its eatable quality. The Widgeon is the most perfectly proportioned of any water-fowl, and the plumage of the male is peculiarly bright and beautiful. Both on land and in the water it is very active; when on shore it walks upright and rapidly, and on the water is unrivalled in swimming. The nest is similar to that of other water-birds, the eggs being well protected by the down of the female. The young, when hatched, have rather a brown-than a green-coloured covering, in this also differing from the common duck, teal, \&c."

Mr. Dann informed Mr. Yarrell that the Widgeon " is the most abundant of all the Duck tribe in Lapland, frequenting the grassy swamps, lakes, and rivers. They appear with the first breaking-up of the ice, in pairs; and as soon as the females begin to lay, the male loses his beautiful plumage, and secretes himself in willowswamps and in the most inaccessible morasses; nor does he recover his former appearance until November or December. The females lay from five to eight eggs. They also breed on the Dovre fjeld, as high as the birch grows, and in many other parts of Norway and Sweden, but only in straggling pairs. They migrate south early in September, appearing in great flocks on the coasts of Norway and Sweden. The young keep among the rushes and reeds in the lakes, the old birds betaking themselves to the shallows on the coast. They entirely leave Sweden in the winter."

The following interesting note respecting this species was communicated to the late Sir John Richardson by the Rev. Mr. Booth, of Friskney, in Lincolnshire:- "Skelton tells me that the Widgeon does not willingly dive : of course, if driven to it, it can; but it does not dive for its food; and though in play it sometimes splashes under water, it never remains beneath the surface. The Widgeon is ' an amazing foul to graze, a strange eater of grass.' It is especially fond of 'flutter-grass' (Glyceria aquatica vel fluitans ?), which it crops on the surface; but it likewise eats many other herbs. When the decoy has been so full of Widgeons that they have devoured every blade on the landings, Skelton has taken advantage of their absence in the night, when they resort to the salt marshes on the sea-coast, and laid down sods pared from the fields, on which they readily graze. In common with the Mallard, Teal, and Pintail, they are very fond of Willowweed seeds (Epilobium), with which he feeds all the fowl in the decoy, as they prefer it to oats and every other kind of grain."-Faun. Bor.-Amer. vol. ii. p. 436, note.

Dr. Jerdon, speaking of the Widgeon in India, remarks that it "cannot be said to be either common or abundant, although it is met with occasionally in every part of the country in small or moderate flocks."

The Widgeon emits, chiefly during flight, a peculiarly shrill whistling note, which has obtained for it, in some parts of England, the name of Whew Duck; and its French name of Canard siffeur has reference to the same sound.

During the proper season great numbers of Widgeons are taken in the decoys; and we have the authority of Colonel Hawker that, like the fox in hunting, it affords the finest sport for coast night-shooting, ample directions for which will be found in that gentleman's well-known work on sport and sporting.

Mr. Thompson, after stating that the Widgeon frequents the marine loughs \&c. of Ireland in great numbers for above six months of the year, gives an interesting account of the modes of shooting it, \&c., to which, as it is too lengthy for extract, I must refer my readers (see his 'Natural History of Ireland,' vol. iii. p. 100 et seq.).

The Plate represents a male and a female, about the natural size. 


\section{$2 \mathrm{BHL}$ Biodiversity Heritage Library}

Gould, John. 1873. "Widgeon, Mareca penelope [PI. 13]." The birds of Great Britain 5, -. https://doi.org/10.5962/p.324057.

View This Item Online: https://www.biodiversitylibrary.org/item/222497

DOI: https://doi.org/10.5962/p.324057

Permalink: https://www.biodiversitylibrary.org/partpdf/324057

\section{Holding Institution}

Smithsonian Libraries

\section{Sponsored by}

Biodiversity Heritage Library

\section{Copyright \& Reuse}

Copyright Status: Public domain. The BHL considers that this work is no longer under copyright protection.

This document was created from content at the Biodiversity Heritage Library, the world's largest open access digital library for biodiversity literature and archives. Visit BHL at https://www.biodiversitylibrary.org. 